\title{
The Different of Finger Handheld and Deep Breathing Relaxation Techniques Effect on Reducing Heart Rate and Stress Levels in Primary Hypertension Patients
}

\author{
Arif Setyo Upoyo, Agis Taufik \\ Faculty of Health Sciences, Universitas Jenderal Soedirman, Purwokerto, Indonesia \\ Corresponding email:afkarfadholi@gmail.com
}

Submitted: 03-09-2018 Accepted: 27-11-2019 Published: 05-12-2019

\begin{abstract}
Stress and hypertension have a reciprocal relationship where hypertension can increase stress, and stress will also increase blood pressure. Therefore we need an effort to control stress in patients with hypertension to prevent increasing blood pressure that can cause complications such as congestive heart failure, myocardial infarction, and stroke. The study aimed to determine the difference between finger handheld and deep breathing relaxation techniques to decrease heart rate and stress levels of primary hypertension patients. The research design used a quasi-experimental design. The research was conducted in Kembaran and East Purwokerto District, Banyumas, Indonesia. There were 50 respondents ( 25 finger handheld relaxation group and 25 respondents in deep breathing relaxation group). Heart rate and stress levels were measured before and after treatment using heart rate (HR) recordings on digital tensimeter and Subjective Units of Distress Scale (SUDS). Data analyzed using a paired t-test and independent t-test. The results showed there were significant differences in HR and stress levels before and after finger handheld relaxation $(p=0.000)$. There were significant differences in HR $(p=0.010)$ and significant levels of stress $(p=0.000)$ before and after deep breathing relaxation. There was a significant difference in HR ( $p$ $=0.02)$ but there was no significant difference in stress levels $(p=0.23)$ after treatment (post-test) between those who received finger handheld and deep breathing relaxation techniques. Conclusion: finger handheld and deep breathing relaxation techniques are equally effective in reducing stress levels in primary hypertension patients. Finger handheld relaxation technique is more effective in reducing HR than a deep breathing relaxation technique.
\end{abstract}

Keywords: Finger handheld, heart rate, hypertension, relaxation, stress. 
Arif Setyo upoyo: The Different of Finger handheld and Deep Breathing Relaxation Techniques Effect

\section{Introduction}

Hypertension becomes one major health problem in the World. The World Health Organization (WHO) and The International Society of Hypertension (ISH) recorded the number of people suffering from hypertension who have already reached 600 million people throughout the world and 3 million people suffering from hypertension die each year. Hypertension is classified into a noncontagious disease with its highest number of $57.87 \%$ in Central Java in 2015 (Dinas Kesehatan Provinsi Jawa Tengah, 2016). Meanwhile, Banyumas Regency ranks fourth with $39.52 \%$. Based on data obtained from the Health Office of Banyumas Regency, patients with hypertension annually increase. In 2016, there were 81,862 people with hypertension at the age of $\geq 18$ years old. Kembaran and East Purwokerto are two districts with those suffering from hypertension (Dinas Kesehatan Kabupaten Banyumas, 2016).

Hypertension may be influenced by several factors, such as age, sex, genetic, smoking habits, obesity, stress, exercising habits, coffee consumption, high sodium diet and alcohol consumption (Andria, 2013; Wahyuningsih \& Astuti, 2013; Rahmawati \& Daniyati, 2016). The research conducted by Mucci et al. (2016) stated that psychological stress significantly influences the systolic blood pressure. An individual with a highstress level has a $21 \%$ higher risk to experience high blood pressure than those with lower stress level (Gasperin et al., 2009). If the stress increases, the hypertension risk will also increase (Liu et al., 2017). Uncontrolled hypertension causes complex problems experienced by patients as a complication of hypertension. The patient's ability to perform self-care agency, psychological stress control is very important and recommended for controlling hypertension (Dendy et al., 2018). Chronic stress and mal-adaptive ability to respond to stress may strongly influence the blood pressure increase (Sparrenberger et al., 2009). When experiencing stress, the arteries which supply the organ functions will be narrower than the blood pressure may increase (Yulianto et al., 2017). Stress condition will cause artery constriction that results in increasing perifer resistance. This condition results in hypertension (Fuchs et al., 2009).

The research conducted by Erris and Rahman (2016) shows that people suffering from hypertension will experience stress because when facing problems, they are unable to control their emotions and anger. They also do not have an awareness to find information to deal with their stress. In addition, the respondents are also less active to do self-relaxation to reduce their own stress. Psychological or mental stress was associated with an increased risk for hypertension ( $\mathrm{Hu}$ et al., 2015; Jadhav et al., 2014).

Stress stimulates the sympathetic nervous system to increase the cardiac output and arteriolar vasoconstriction, which eventually increases the blood pressure. Stress also stimulates the adrenal gland to release adrenal hormones and stimulate the heart to beat faster and stronger than the blood pressure may increase (Haryono et al., 2016). Thus, an effort to control stress in patients suffering from hypertension is greatly required to prevent the increasing blood pressure which may cause complications, such as congestive heart failure, myocardial infarction, and stroke (Rainforth et al., 2007).

One technique to reduce stress is relaxation. This technique can deliberately overcome and repair patients to deliberately make their body muscles (Sulistyarini, 2013). Effective relaxation therapy for reducing depression, coping, and stress (Kashani et al., 2012). Relaxation therapies that can be used to reduce pain and recovery are Finger Held and deep breathing (Yulastuti, 2015; Sari, 2016; Mason et al, 2013). Relaxation of finger holding is part of Jin Shin Jyutsu (Japanese acupressure)) which is very easy and easy to do for anyone related to fingers and energy flow in our body (Pinandita et al., 2012; Idris \& Astarani, 2017). This technique uses simple hand touches that involve breathing to balance the energy in our body to control our emotions to be relaxed (Sari, 2016; Idris \& Astarani, 2017). This relaxed feeling can eliminate muscles and reduce difficulties (Yuliastuti, 2015). Deep breathing relaxation can increase oxygen saturated and relax condition (Mason et al, 2013). The results of research conducted by Rosliana et al. (2018) provide five-finger relaxation 
Arif Setyo upoyo: The Different of Finger handheld and Deep Breathing Relaxation Techniques Effect

therapy that improves sleep quality in breast cancer patients.

This research aims at examining the difference between finger-holding and deep breathing relaxation techniques on reducing the heart rate and stress levels in patients suffering from hypertension.

\section{Method}

This quasi-experimental research compares two treatment groups (finger held and deep breathing relaxation) as an independent variable with heart rate and stress level as dependent variables among primary hypertension patients. This research was conducted in Kembaran and East Purwokerto district which has a high prevalence of patients suffering from high hypertension in Banyumas. The population in this study were all hypertension patients in the PUSKESMAS Kembaran Timur Purwokerto in the last 3 months. The sampling technique was a Purposive sampling approach. The inclusion criteria in this research are patients suffering from primary hypertension with the blood pressure of $\geq 140 / 90 \mathrm{mmHg}$ and willing to become the research respondents. Meanwhile, the exclusion criteria in this research are patients who do not participate in the therapy, with hearing problems, and experience complications with the other diseases (kidney disease, heart disease, diabetes mellitus, and stroke). The obtained research samples are 50 patients, from the results of calculations of the average hypothesis test of two populations. consisting of 25 patients receiving fingerholding relaxation techniques and 25 patients receiving deep-breathing relaxation techniques that guided by the researcher for 15-20 minutes.

The demographic questionnaire was used to identify the respondents' characteristics including age, sex, and blood pressure. The Subjective Units of Distress Scale (SUDS) was employed to measure the stress level. The inconvenience feeling measured with SUDS greatly depends on the current situation that it is quite sensitive to measure the occurring stress level changes (Astri, 2012). SUDS consists of 11 multilevel answer points of Likert scales, starting from 0 points, in which there is no stress at all or relax up to 10 points (the highest stress level). To measure the heart rate (HR), a record on the Medel digital tension-meter licensed by the European hypertension association with technically identical to KD-5915.

The research data were analyzed using univariate and bivariate analysis. Univariate analysis is conducted on each research variable to explain the characteristics of age, sex, systolic blood pressure and diastolic blood pressure then presented in the form of distribution, frequency and percentage.

Data analyzed using a paired t-test and independent t-test. Bivariate analysis is conducted to determine the heart rate and stress level differences in the control and intervention group before and after treated with finger-holding and deep-breathing relaxation techniques. Data analyzed using a paired t-test and independent $t$-test within spss 16. The degree of significance is determined by the if value of sig $p \leq 0.05$ then the hypothesis of the study is accepted.

This research is conducted after obtaining the approval from the board of health research ethics, Faculty of Medicine, Sebelas Maret University, Surakarta (No. 221/II/ HREC/2018).

\section{Results}

\section{Respondents' Characteristics}

The respondents' characteristics in this research are shown in Table 1 and 2. The respondents are mostly female at the age of more than 60 years old. The respondents' characteristics illustrated in table 2 show that most respondents have the blood pressure of $>160 \mathrm{mmHg}$. Based on the Joint National Committee on Prevention, Detection, Evaluation, and Treatment of High Blood Pressure (JNC), those respondents are classified into hypertension stage 2 . There is no systolic and diastolic blood pressure significant difference in the group treated with a finger-holding relaxation technique and the group treated with and deep-breathing relaxation technique that eventually reduces the blood pressure influence on the heart rate and anxiety level measurement result. 
Arif Setyo upoyo: The Different of Finger handheld and Deep Breathing Relaxation Techniques Effect

Table 1 Respondents' Characteristics Based on Age and Sex

\begin{tabular}{lccccc}
\hline Characteristics & \multicolumn{2}{c}{ Finger-holding group (n=25) } & \multicolumn{2}{c}{ Deep-breathing group (n=25) } & p \\
\cline { 2 - 5 } & $\mathbf{f}$ & $\mathbf{\%}$ & $\mathbf{f}$ & $\mathbf{\%}$ & \\
\hline Age (Year) & & 10 & 0 & 0 & 0.013 \\
45-59 (middle & 5 & & & & \\
age) & 20 & 40 & 24 & 48 & \\
60-74 (elderly) & 0 & 0 & 1 & 2 & \\
$75-90$ (old) & 61.80 & $(6.61)$ & 68.84 & $(4.85)$ & \\
Mean (SD) & & & & & \\
Sex & 6 & 12 & 2 & 4 & 0.247 \\
Male & 19 & 38 & 23 & 46 & \\
Female & & & &
\end{tabular}

Table 2 Respondents' Characteristics Based on Systole dan Diastole Blood Pressure

\begin{tabular}{lccccc}
\hline $\begin{array}{c}\text { Characteristics } \\
\text { of Blood } \\
\text { Pressure }\end{array}$ & $\begin{array}{c}\text { Finger-holding group (n=25) } \\
\text { Mean }\end{array}$ & SD & \multicolumn{2}{c}{ Deep-breathing group (n=25) } & Mean \\
\hline Sistole & 164.08 & 12.93 & 168.28 & 21.94 & 0.415 \\
Diastole & 101.64 & 9.37 & 98.52 & 14.94 & 0.381 \\
\hline
\end{tabular}

After the age of 60 years old (elderly), the prevalence of hypertension increases due to the vascular changes resulted from the plaque accumulation at the vascular endothelium which may increase the peripheral resistance and resulted is in blood pressure increase. Age factor greatly influences the presence of hypertension. The increasing age also increase the risk of experiencing hypertension due to physiological changes resulted from the body degenerative processes.

The hypertension experienced by the women is higher than that experienced by men after reaching the age of 60 years old as women experience menopause (Smeltzer $\&$ Bare, 2008). After menopause, the women usually experience hormonal changes which may increase the fat accumulation in vascular endothelium that the hypertension risk continuously increases. Based on the statistical data, there is a significant relationship between mental stress and hypertension in men (Jadhav et al., 2014).
The respondents' characteristics illustrated in table 2 show that most respondents have the blood pressure of $>160 \mathrm{mmHg}$. Based on the Joint National Committee on Prevention, Detection, Evaluation, and Treatment of High Blood Pressure (JNC), those respondents are classified into hypertension stage 2. There is no systolic and diastolic blood pressure significant difference in the group treated with finger-holding relaxation technique and the group treated with and deep-breathing relaxation technique that eventually reduces the blood pressure influence on the heart rate and anxiety level measurement result.

The Heart Rate and stress level difference before and after the intervention.

The result of the analysis shows that there is significant heart rate and stress level difference before and after the intervention. After the intervention, both groups show the decreasing heart rate and stress level (see Table 3).

Table 3 The Heart Rate and Stress Level of Patients Suffering from Primary Hypertension Before and After Treatment

\begin{tabular}{ccccccc}
\hline $\begin{array}{c}\text { Relaxation } \\
\text { Group }\end{array}$ & Mean & Before & & & After & \\
& & SD & Mean & & SD & \\
\hline
\end{tabular}

Finger-holding 
Arif Setyo upoyo: The Different of Finger handheld and Deep Breathing Relaxation Techniques Effect

\begin{tabular}{lccccc}
\hline Heart Rate & 84.80 & 9.40 & 80.40 & 9.08 & 0.000 \\
Stress level & 4.16 & 2.34 & 3.12 & 2.11 & 0.000 \\
Deep-breathing & & & & 12.53 & 0.010 \\
Heart Rate & 90.16 & 12.09 & 87.84 & 2.29 & 0.000 \\
Stress level & 4.96 & 2.49 & 3.84 & & \\
\hline
\end{tabular}

Table 4 The Pre and The Post-Test Difference Between The Patients' Heart Rate Treated with Finger-Holding and Those with Deep-Breathing Intervention

\begin{tabular}{lccccc}
\hline \multicolumn{1}{c}{ Variable } & \multicolumn{2}{c}{ Finger-holding } & \multicolumn{2}{c}{ Deep-breathing } & p \\
& Mean & SD & Mean & SD & \\
\hline Heart Rate & & & & & \\
Pre Test & 84.80 & 9.40 & 90.16 & 12.09 & 0.09 \\
Post-test & 80.40 & 9.08 & 87.84 & 12.52 & 0.02 \\
Decrease & 4.40 & 3.90 & 2.32 & 4.15 & 0.07 \\
Stress level & & & & & \\
Pre Test & 4.16 & 2.34 & 4.96 & 2.49 & 0.28 \\
Post-test & 3.12 & 2.11 & 3.84 & 2.29 & 0.23 \\
Decrease & 1.04 & 1.02 & 1.12 & 0.78 & 0.08 \\
\hline
\end{tabular}

The stress level measurement in both groups with SUDS shows that the average stress level is categorized into moderate before treatment but changed into mild after the treatment. It shows that there is a significant stress level decrease experienced by both groups.

The heart rate measurements before treatment in both groups show that there is no significant difference, yet after the measurement, there is a heart rate significant difference (see table 4). The average decreasing heart rate in the group treated with finger-holding relaxation intervention is better than that treated with deep-breathing relaxation intervention, in which the heart rate decrease in the group treated with fingerholding relaxation intervention is 4.4 times/ minute, while that in the group treated with deep-breathing relaxation intervention is 2.32 times/minute.

The result of the analysis on stress level shows that there is no significant difference in both groups' pretest and posttest result. However, the average stress level decrease experienced by the group treated with deepbreathing relaxation intervention is better than the group treated with finger-holding relaxation intervention. The stress level experienced by the group treated with finger- holding relaxation intervention decreases by 1.04 , while the group treated with deepbreathing relaxation intervention decreases by 1.12 .

The result of analysis on stress level shows that there is no significant difference in both groups' pretest and posttest result. However, the average stress level decrease experienced by the group treated with deep-breathing relaxation intervention is better than the group treated with finger-holding relaxation intervention. The stress level experienced by the group treated with finger-holding relaxation intervention decreases by 1.04 , while the group treated with deep-breathing relaxation intervention decreases by 1.12 .

Both interventions are effective to reduce the stress level. Finger-holding relaxation intervention may relieve the stressful feelings, reduce tension, increase comfort, and help deal with the uncontrolled situations due to the stress without changing the underlying stress causes (National Center on Domestic Violence, Trauma \& Mental Health, 2014). Meanwhile, deep-breathing relaxation may effectively induce the development of mood and control the stress (Perciavalle et al., 2017).

The decreasing stress level and heart rate positive influence the patients suffering from 
Arif Setyo upoyo: The Different of Finger handheld and Deep Breathing Relaxation Techniques Effect

hypertension (Rodrigues et al., 2018). The combination of the increased mental and physical stress may significantly increase the systolic blood pressure (Trapp et al., 2014), while the decreasing stress level may increase the telomerase gene expression and reduce the blood pressure (Duraimani et al., 2015).

\section{Discussion}

The heart rate decrease experienced by both groups is due to the finger-holding and deep-breathing intervention to result in the relaxation response. The relaxation response may influence the limbic system in synchronizing the brain waves to the wave $\alpha$ to create a relaxing feeling responded by hypothalamus by reducing the secretion of Corticotropin-Releasing Hormone (CRH), which may also stimulate the anterior pituitary gland to reduce the secretion of Adrenocorticotropic Hormone (ACTH) (Rosaline et al., 2017). The sympathetic stimulation decrease may reduce the heart rate frequency (weinschenk et al., 2016). The result of this research is in line with that conducted by Perciavalle et al. (2017) stating that the relaxation techniques may improve mood and reduce the heart rate and cortisol salivary level.

Both interventions are effective to reduce the stress level. Finger-holding relaxation intervention may relieve the stressful feelings, reduce tension, increase comfort, and help deal with the uncontrolled situations due to the stress without changing the underlying stress causes (National Center on Domestic Violence, Trauma \& Mental Health, 2014). Meanwhile, deep-breathing relaxation may effectively induce the development of mood and control the stress (Perciavalle et al., 2017). Pursed lips breathing (PLB) is a breathing technique that can be used to help breathe more effectively and can increase oxygen saturation (Suryantoro et al., 2017). Pursed lips breathing trains Chronic obstructive pulmonary disease sufferers to exhale slower, so that they will breathe easier and feel comfortable, both when resting (Eko et al., 2017).

The finger-holding relaxation technique is more effective to reduce the heart rate because this technique combines the fingerholding and deep-breathing technique to control emotion and stress (National Center on Domestic Violence, Trauma \& Mental Health, 2014). The controlled stress may result in the decreasing cortisol hormone and sympathetic response that eventually reduce the heart rate. Deep-breathing may activate the baroreceptors which stimulate the parasympathetic nerves to reduce the heart rate (Mason et al., 2013).

The decreasing stress level and heart rate positive influence the patients suffering from hypertension. The combination of the increased mental and physical stress may significantly increase the systolic blood pressure (Trapp et al., 2014), while the decreasing stress level may increase the telomerase gene expression and reduce the blood pressure (Duraimani et al., 2015).

\section{Limitation study}

The intervention in this study was only one session. There is an age difference between the group held by the fingers and the group breathing deeply. this is due to weaknesses in the sampling technique carried out by researchers.

\section{Conclusion}

Both finger and deep breathing techniques are equally effective in reducing stress levels experienced by patients suffering from primary hypertension. The relaxation technique holding the fingers is more effective in reducing heart rate than the deep breathing relaxation technique. The research needs to be continued with several different interventions and measurements and sampling techniques

\section{Acknowledgment}

Thanks to the LPPM of Unsoed, Purwokerto for funding this research through its research grant in the Competency Improvement Scheme.

\section{References}

Andria, K.M., 2013, Hubungan antara perilaku olahraga, stres, dan pola makan 
Arif Setyo upoyo: The Different of Finger handheld and Deep Breathing Relaxation Techniques Effect

dengan tingkat hipertensi pada lanjut usia di Posyandu Lansia Kelurahan Gebang Putih Kecamatan Sukolilo Kota Surabaya. (The relationship between exercise behavior, stress, and diet with the level of hypertension in the elderly at the Posyandu Lansia, Gebang Putih Village, Sukolilo District, Surabaya). Jurnal Promkes, 2 (1) : 111-117.

Astri, K. (2012). Manajemen stres dan kesepian dengan multicomponent cognitive behavioral group therapy (MCBGT) pada lansia. (Stress and loneliness management with multicomponent cognitive behavioral group therapy (MCBGT) in the elderly). Tesis. Program Studi Psikologi Profesi Universitas Indonesia, Jakarta.

Dendy, K., Helwiyah, R., Rahayu, U. (2018). The factors that are related to self-care agency in patients with hypertension. Jurnal Keperawatan Padjadjaran, 6(1), 1-17.

Dinas Kesehatan Kabupaten Banyumas. (2016). Profil kesehatan Kabupaten Banyumas tahun 2016. (2016 Banyumas District Health Profile). Purwokerto: Dinas Kesehatan Kabupaten Banyumas.

Dinas Kesehatan Provinsi Jawa Tengah. (2015). Profil kesehatan Provinsi Jawa Tengah. (Central Java Province Health Profile). Semarang: Dinas Kesehatan Provinsi Jawa Tengah.

Duraimani, S., Schneider, R.H., Randall, O.S., Nidich, S.I., Xu, S., Ketete, M., et al. (2015). Effects of lifestyle modification on telomerase gene expression in hypertensive patients: A pilot trial of stress reduction and health education programs in African Americans. PLoS ONE 10(11), e0142689.

Eko, S., Arif, S.U., Atyanti, I. (2017). Perbedaan efektivitas pursed lips breathing dengan six minutes walk test terhadap forced expiratory. Jurnal Keperawatan Unpad, 5(2), 99-112.

Erris \& Rahman. (2016). Hubungan riwayat keluarga dan tingkat stres pasien dengan kejadian hipertensi di Puskesmas Putri Ayu Kota Jambi tahun 2015. (Relationship between family history and stress level of patients with hypertension at Putri Ayu Health Center Jambi in 2015). Scientia Journal, 5(2), 131-136.

Fuchs, S.C., Moreira, L.B., Fuchs, F.D. (2009). Does psychosocial stress cause hypertension?: A systematic review of observational studies. Journal of Human Hypertension, 23, 12-19.

Gasperin, D., Netuveli, G., Dias-daCosta, J.S., Pattussi, M.P. (2009). Effect of psychological stress on blood pressure increase: A meta-analysis of cohort studies. Cad. Saúde Pública, Rio de Janeiro, 25(4), 715-726.

Haryono, R., Permana, I., \& Chayati, N. (2016). Pengaruh kombinasi pijat punggung dan dzikir terhadap tingkat stres pada penderita hipertensi. (The effect of a combination of back massage and dhikr on stress levels in patients with hypertension). Jurnal Keperawatan Notokusumo, 6(1), 1221.

Hu, B., Liu, X., Yin, S., Fan, H., Feng, F., et al. (2015). Effects of psychological stress on hypertension in middle-aged chinese: a cross-sectional study. PLOS ONE 10(6), e0129163. https://doi.org/10.1371/journal. pone. 0129163 .

Idris, D.N.T., \& Astarani, K. (2017). Terapi relaksasi genggam jari terhadap penurunan nyeri sendi pada lansia. (Finger handheld relaxation therapy to reduce joint pain in the elderly). Jurnal Penelitian Keperawatan, 3(1), 23-32.

Jadhav, S.B., Jatti, G.M, Jadhav, A.S, Rajderkar, S.S., Naik, J.D., Nandimath, V.A. (2014). Stressing 'Mental Stress' in hypertension: A rural background study. Journal of Clinical and Diagnostic Research, 8(6), JC04-JC07.

Kashani, F., Babaee, S., Bahrami, M., \& Valiani, M. (2012). The effects of relaxation on reducing depression, anxiety and stress in women who underwent mastectomy for breast cancer. Iran J Nurs Midwifery Res., 
Arif Setyo upoyo: The Different of Finger handheld and Deep Breathing Relaxation Techniques Effect

17(1), 30-33.

Liu, M.Y., Li, N., Li, W.A., \& Khan, H. (2017). Association between psychosocial stress and hypertension: A systematic review and meta-analysis. A Journal of Progress in Neurosurgery, Neurology, and Neurosciences, $39,573-580$.

Mason, Vandoni, de Barbieri, Cordans, Ugargol, \& Bernadi, (2013). Cardiovascular and respiratory effect of yogic slow breathing in the yoga beginner: What is the best approach?. Complementary and alternative medicine, 743504.

Mucci, N., Giorgi, G., De Pasquale Ceratti, S., Fiz-Pérez, J., Mucci, F., \& Arcangeli, G. (2016). Anxiety, stress-related factors, and blood pressure in young adults. Front. Psychol. 7, 1682.

National Center on Domestic Violence, Trauma, andMentalHealth.(2014).Fingerhold practice for managing emotions and stress. http://www.nationalcenterdvtraumamh.org accessed on 26 Oktober 2017.

Perciavalle, V., Blandini, M., Fecarotta, P., Buscemi, A., Di Corrado, D., Bertolo, L., Fichera, F., \& Coco, M. (2017). The role of deep breathing on stress. Neurological Sciences, 38(3), 451-458.

Pinandita, I., Purwanti, E., \& Utoyo, B. (2012). Pengaruh teknik relaksasi genggam jari terhadap penurunan intensitas nyeri pada pasien post operasi laparotomi. (The effect of fingerhold relaxation techniques on reducing pain intensity in post-laparotomy patients). Jurnal Ilmiah Kesehatan Keperawatan, 8(1), $32-43$.

Rahmawati, R., \& Daniyati, D. (2016). Hubungan kebiasaan minum kopi terhadap tingkat hipertensi. (The relationship between coffee drinking habits and hypertension level). Journal of Ners Community, 2(7), 149-161.

Rainforth, M.V., Schneider, R.H., Nidich, S.I., King, C.G., Salerno, J.W., \& Anderson, J.W. (2007). Stress reduction programs in patients with elevated blood pressure: A systematic review and meta-analysis. Curr Hypertens Rep., 9(6), 520-528.

Rodrigues, G.D., Gurgel, J.L., Gonçalves, T.R., Porto, F., \& Soares. (2018). Influence of breathing patterns and orthostatic stress on postural control in older adults. Geriatr Gerontol Int., 18(5), 692-697.

Rosliana, D., Laili, R., \& Titis, K. (2018). The effect of five-finger relaxation technique to the sleep quality of breast cancer patients. Jurnal Keperawatan Unpad, 6(2), 183-192.

Sari, R.D.K. (2016). Pegaruh teknik relaksasi genggam jariterhadap penurunan kecemasan pada pasien pre operasi sectio caesarea. (The effect of handgrip relaxation techniques on reducing anxiety in preoperative sectio caesarea patients). Publikasi Ilmiah. Jurusan Keperawatan Universitas Muhammadiyah Surakarta, Surakarta.

Smeltzer, S.C., Bare, B.G., Hinkle, J.L., \& Cheever, K, H. (2008). Textbook of MedicalSurgical Nursing. Eleventh edition. Brunner, \& Suddarth's. Philadelphia. Lippincott Williams \& Wilkins.

Sulistyarini, I. (2013). Terapi relaksasi untuk menurunkan tekanan darah dan meningkatkan kualitas hidup pederita hipertensi. (Relaxation therapy to lower blood pressure and improve the quality of life for hypertensive patients). Jurnal Psikologi, 1(40), 28-38.

Suryantoro, E., Isworo, A., \& Upoyo, A.S. (2017). Perbedaan efektivitas pursed lips breathing dengan six minutes walk tes terhadap forced expiratory. (Differences in the effectiveness of pursed lips Breathing with Six-Minute Walk Test against forced expiratory). Jurnal Keperawatan Padjajaran, 5(2), 99-112.

Trapp, M., Trapp, E-M., Egger, J.W., Domej, W., Schillaci, G., et al. (2014) Impact of mental and physical stress on blood pressure and pulse pressure under normobaric versus hypoxic conditions. PLOS ONE, 9(5), e89005.

Wahyuningsih \& Astuti, E. (2013). Faktor 
Arif Setyo upoyo: The Different of Finger handheld and Deep Breathing Relaxation Techniques Effect

yang mempengaruhi hipertensi pada usia lanjut. (Factors that influence hypertension in the elderly). Jurnal Ners dan Kebidanan Indonesia, 1(3), 71-75.

Weinschenk, S.W., Beise, R.D., \& Lorenz, J. (2016). Heart rate variability (HRV) in deep breathing tests and 5-min short-term recordings: agreement of ear photoplethysmography with ECG measurements, in 343 subjects. Eur $J$ Appl Physiol., 116(8), 1527-35.

Yulianto, Sari, S.M., \& Lestari, Y.A. (2017). Pengaruh terapi relaksasi autogenik terhadap perubahan tekanan darah pada lansia dengan hipertensi di UPT Panti Werdha Mojopahit Mojokerto. (The effect of autogenic relaxation therapy on changes in blood pressure in the elderly with hypertension at UPT Panti Werdha Mojopahit Mojokerto). Jurnal Keperawatan dan Kebidanan, 9(1), 8-18.

Yuliastuti, C. (2015). Effect of handheld finger relaxation on the reduction of pain intensity in patients with post-appendectomy at inpatient ward RSUD Sisoarjo. International Journal of Medicine and Pharmaceutical Sciences (IJMPS), 5(3), 53-58. 